\section{Assessing water quality by remote sensing in small lakes: the case study of Monticchio lakes in southern Italy}

\begin{abstract}
Mancino $G^{(1)}$, Nolè $A^{(1)}$, Urbano $V^{(2)}$, Amato $M^{(1)}$, Ferrara $A^{(1)}$
In order to investigate bio-physical parameters associated with water quality, a model based on calibrated and atmospherically corrected Remotely Sensed data has been implemented. Secchi Disk depth and chlorophyll concentration parameters were estimated in a system of very small lakes at Monticchio (Italy) using Landsat TM data. The model was developed through the use of stepwise multiple regression and gave high coefficients of determination $\left(R^{2}=0.82\right.$ for Secchi Disk and $\mathrm{R}^{2}=\mathbf{0 . 7 2}$ for chlorophyll). Values for water transparency were strongly correlated with chlorophyll a concentration: a linear relationship between the two parameters showed a high coefficient of determination $\left(R^{2}=\right.$ 0.93). The case study shows that the application of this approach on lakes with a small surface area, such as the Monticchio lakes in Southern Italy, is effective and the developed model well describes the water quality parameters.
\end{abstract}

Keywords: Water quality, Landsat, chlorophyll, Secchi Disk transparency, Remote Sensing, Monticchio Lakes

\section{Introduction}

Assessing the quality of surface water in lakes, rivers and reservoirs is a key issue for environmental monitoring and management. In Europe, lakes are classified according to eco-regions (Brivio et al. 2001b), ranging from alpine to boreal, from continental to sub-arctic. Each class is based on morphological, vegetational and climatic conditions, which influence the water quality parameters such as chlorophyll concentration, turbidity, suspended sediments, and thermal characteristics. Furthermore, lakes are often subjected to sudden environmental changes caused by anthropic activities due to their multiple uses (recreational, industrial, agricultural, water supply, etc.). In order to assess lake water quality, in situ traditional methods are very accurate but have the disadvantage of being invasive, expensive and labour-inten-

(1) Department of Crop Science, Forest and Environment, University of Basilicata, Potenza (Italy); (2) International PhD in "Crop system, Forest and Environmental Sciences", University of Basilicata, Potenza (Italy)

\section{(a) Agostino Ferrara}

(agostino.ferrara@unibas.it)

Received: Apr 29, 2009 - Accepted: May 23, 2009

Citation: Mancino G, Nolè A, Urbano V, Amato M, Ferrara A, 2009. Assessing water quality by remote sensing in small lakes: the case study of Monticchio lakes in southern Italy. iForest 2: 154-161 [online: 2009-07-30] URL: http://www.sisef.it/iforest/show.php? id $=507$ sive. In situ methods, therefore, may undersample the spatial variability required for the proper monitoring and management of lake water quality. Remote sensing provides an efficient method to enhance the in situ limnological measurements, allowing the extension of the recorded parameters to the entire lake surface.

Remotely sensed data from satellites have been used for the monitoring of water quality (Lathrop \& Lillesand 1986, Schiebe et al. 1992, Schneider \& Mauser 1996) since the early ' 80 s. The Thematic Mapper sensor installed on the Landsat satellite has been the most widely used sensor to monitor internal waters (Ritchie et al. 1990, Mayo et al. 1995, Kloiber et al. 2002a, Kloiber et al. 2002b, Wang et al. 2004). Thanks to its good spectral characteristics and its finer spatial resolution ( $30 \mathrm{~m}$ pixels), which allowed even small lakes to be investigated, it was particularly popular in Europe (Jaquet \& Zand 1989, Baban 1993, Dekker \& Peters 1993, Zilioli et al. 1994, Zilioli \& Brivio 1997, Brivio et al. 2001a, Brivio et al. 2001b). Sea and ocean water monitoring also increasingly uses data from remote sensors (i.e., Aqua-MODIS, Envisat-AATSR - Strombeck et al. 2003, Giardino et al. 2005, Candiani et al. 2005), which guarantee repetitiveness, improving the detection of limnological parameter changes. But for lake areas with a small extension, where water monitoring is a crucial issue, the coarse resolution of such kind of sensors is not applicable.

Remote sensing water quality assessment, is usually investigated using the optical bands in the region from blue to near in- frared. These data are then used to explore the relation between the reflectance of water bodies and biophysical parameters such as: transparency, chlorophyll concentration (phytoplankton), and the organic and mineral suspended sediments.

The first approach in the lake water quality assessment has been the analysis of chromatic coordinates in the visible part of the electromagnetic spectrum. This approach is based on the idea that an increase of radiance or reflectance at long wavelengths is an indicator of a decrease of spectral response, whereas a reduction of the spectral response towards the shorter wavelengths (blue) is related to an increase in chlorophyll or suspended solid sediments. Although this methodology has been applied by several studies (Bukata et al. 1983, Lindell et al. 1986, Jaquet \& Zand 1989, Zilioli et al. 1993), the results at high chlorophyll and/or suspended solid sediments concentrations are ambiguous (Giardino 2006). Many studies focus on chlorophyll concentration (Ritchie et al. 1990, Dekker \& Peters 1993, George 1997, Brivio et al. 2001a, Brivio et al. 2001b), Bukata et al. (1995) demonstrated that increasing chlorophyll concentration causes a decrease in the spectral response at short wavelengths, particularly in the blue band.

Several studies investigated the correlation between spectral response of internal waters with water transparency using single Landsat bands in the visible region (Giardino et al. 2001), or some combination thereof (Kloiber et al. 2002a, Kloiber et al. 2002b). Water transparency, measured as Secchi Disk (SD), is strongly correlated to the spectral response of Landsat bands (Lillesand et al. 1983), especially the blue and red ones (Lathrop 1992, Cox et al. 1998).

Common statistical techniques have been used to study the correlation between spectral data and limnological parameters such as chlorophyll concentration (Baban 1993, Mayo et al. 1995, Gitelson et al. 2000, Brivio et al. 2001a), transparency (Lathrop \& Lillesand 1986, Lathrop 1992, Dekker \& Peters 1993, Fraser 1998, Giardino et al. 2001, Kloiber et al. 2002a, Kloiber et al. $2002 \mathrm{~b}$ ) and suspended soil sediments (Ritchie et al. 1990, Schiebe et al. 1992, Wang et al. 2004).

The atmospheric path between the satellite and the water surface affects the remotely sensed reflectance: therefore data need to be adequately corrected before statistical analysis can be carried out (Kaufman 1989). In quantitative studies the interactions of incident energy with the atmosphere are large enough to significantly affect the incoming radiance, which may compromise the results (Teillet et al. 1997). This is particularly important for surfaces like water, where the re- 
flected light fraction is very low: being around $1-10 \%$ of the sensor-measured radiance (Gordon 1987). As a consequence, the sensor-recorded radiance of the lake surface can be very low compared to the path radiance. Atmospheric correction is also required in cases where multitemporal analysis is used to assess water quality change. Several techniques have been proposed for the atmospheric correction of the remote sensed data (Kaufman \& Sendra 1988, Caselles \& Lopez Garcia 1989, Richter 1990, Fraser et al. 1992, Chavez 1996, Vermote et al. 1997). Many of them are variants of DOS (Dark Object Subtraction) method; more sophisticated techniques (Radiative Transfer Code) usually require in situ measurements of the atmospheric characteristics during the satellite overpass and therefore are more expensive and, above all, not applicable on historical data.

The aim of this study is to assess the reliability of a model based on calibrated and atmospherically corrected remotely sensed data on two adjacent and small volcanic lakes (Lago Grande and Lago Piccolo) in Basilicata Region (Southern Italy) through the analysis of the relationships between Landsat TM data and chlorophyll concentration and water transparency, gathered in a previous study (Dumontet et al. 2001). Among the Italian volcanic lakes the Monticchio lakes, and in particular the Lago Grande, are characterised by a high concentration of phosphorus and nitrogen on the bottom and on the surface as well (Ministero dell'Ambiente e della Tutela del Territorio e del Mare 2007). The raising interest in the study of the eutrophication processes and, in particular in the strategies to reduce them, is also confirmed by a recent study (Leoni \& Garibaldi 2009).

In the present paper the main innovation is represented by the implementation of the proposed Landsat TM based methodology on very small lakes, while so far it has been applied only for very large lakes. In fact, the use of Landsat TM dataset available since the $70 \mathrm{~s}$, even if characterised by a coarse resolution, allows a multitemporal analysis of the internal water quality.

The proposed approach leads also to the implementation of a different functional model (Sass et al. 2007) based on the relation of the two Landsat bands TM1 and TM2, which represents the minimum and maximum reflectance of the chlorophyll $a$ in internal waters (Green 2003, Vincent et al. 2004).

\section{Materials and Methods}

\section{Study area}

The Monticchio lakes system consists of two volcanic basins located in the Vulture mountain range in Basilicata, south Italy

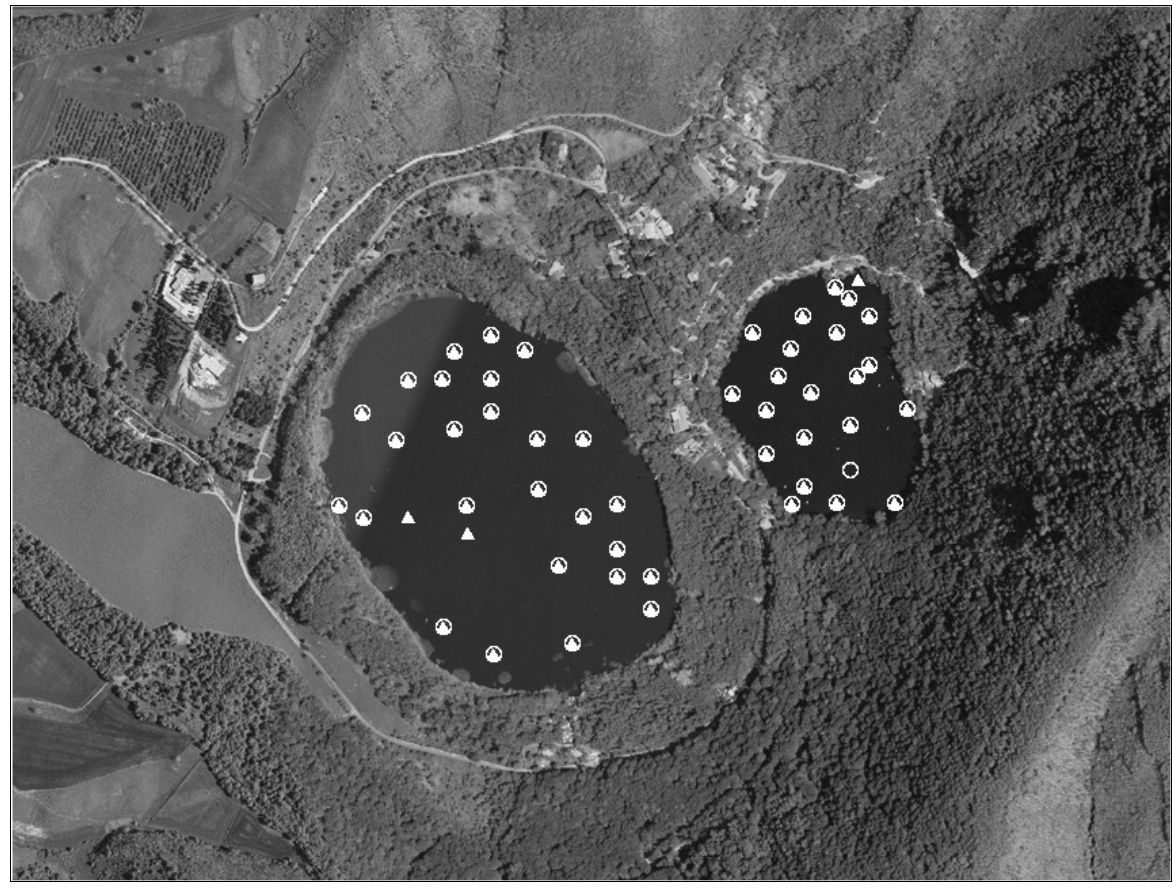

Fig. 1 - Study area $\left(40^{\circ} 55^{\prime} 48.29^{\prime \prime} \mathrm{N} ; 5^{\circ} 36^{\prime} 16.61^{\prime \prime}\right.$ E) with sampling points of Secchi Disk (triangles) and chlorophyll $a$ concentration (circles). Redrawn from Dumontet et al. 2001.

$\left(40^{\circ} 55^{\prime} 48.29^{\prime \prime} \mathrm{N} ; 5^{\circ} 36^{\prime} 16.61\right.$ ” E). The catchment area is about 400 ha and ranges between $1262 \mathrm{~m}$ and $653 \mathrm{~m}$ a.s.l., that represents the inlet of the Lago Grande effluent. The Monticchio lakes system within the whole area of Vulture mountain range belong to the Natura 2000 network of protected areas (European Birds Directive 79/409/CEE and European Habitats Directive 92/43/ CEE).

The two lake basins, with different and relatively considerable depths (Fig. 1) originated from two different volcanic explosions, and are divided by a narrow isthmus and communicate through an interlake canal. The two lakes are fed by both telluric and meteoric waters; Lago Piccolo gets aquifer water directly from the bottom, while Lago Grande gets the excess water from Lago Piccolo through the interlake canal. The Lago Grande outflow leads to the Ofanto River. The morphometric characteristics of the two lakes (Dumontet et al. 2001) are reported in Tab. 1.

\section{Limnological data}

The limnological data on water transparency and chlorophyll $a$ content used in this study were obtained from a wider study (Dumontet et al. 2001), aimed at identifying the morphometrical, limnological and chemicalmicrobiological characteristics of the Monticchio lakes.

Referring to Dumontet et al. (2001) sampling was carried out on May $15^{\text {th }} 2001$ for Lago Piccolo, and May $16^{\text {th }}$ for Lago Grande. The following physico-chemical properties were measured: depth; temperature; transparency (Secchi Disk depth, at the resolution of $25 \mathrm{~cm}$ ); water oxygen; nutrients; $\mathrm{pH}$ and chlorophyll $a$. Transparency was measured at 38 stations in Lago Grande and 22 in Lago Piccolo while chlorophyll $a$ was measured at 22 and 23 stations respectively (Fig. 1).

Among these sampling points, the closest measurements to the coastline were excluded to avoid comparison with Landsat pixels with an ambiguous spectral response due to contamination by any vegetation around the lakes occurring in the pixel footprint. Moreover, given the close proximities of some stations, some sampling points fell into the same pixel. In such cases an arithmetic mean of the measurements was calculated. Finally, as regards the chlorophyll concentration measurements, samples collected near the bottom of the lake were excluded because of

Tab. 1 - Morphometric characteristics of the Monticchio lakes.

\begin{tabular}{lcc}
\hline \multicolumn{1}{c}{ Parameters } & $\begin{array}{c}\text { Lago } \\
\text { Grande }\end{array}$ & $\begin{array}{c}\text { Lago } \\
\text { Piccolo }\end{array}$ \\
\hline $\begin{array}{l}\text { Catchment basin size } \\
(h a)\end{array}$ & 240 & 107 \\
Volume $\left(m^{3} \times 1000\right)$ & 3270 & 2460 \\
Height $(m)$ & 653.7 & 656 \\
Surface $(h a)$ & 41.3 & 13.9 \\
Maximum depth $(m)$ & 36 & 38 \\
Mean depth $(m)$ & 8.9 & 17.9 \\
Interlake channel & \multicolumn{2}{c}{10} \\
flow $(l / s)$ & & \\
\hline
\end{tabular}


Tab. 2 - Descriptive statistics of chlorophyll and transparency in the two lakes.

\begin{tabular}{lcccc}
\hline \multirow{2}{*}{ Indices } & \multicolumn{2}{c}{ Transparency $($ Secchi Disk) $(\boldsymbol{m})$} & \multicolumn{2}{c}{ Chlorophyll $\boldsymbol{a}\left(\boldsymbol{m g} \boldsymbol{m}^{-\mathbf{3}}\right)$} \\
\cline { 2 - 5 } & Lago Grande & Lago Piccolo & Lago Grande & Lago Piccolo \\
\hline Minimum & 0.25 & 3.00 & 4.63 & 1.11 \\
Maximum & 1.00 & 3.75 & 11.35 & 4.57 \\
Mean & 0.83 & 3.25 & 6.93 & 2.45 \\
Range & 0.75 & 0.77 & 6.72 & 3.46 \\
St. Dev. & 0.186 & 0.199 & 1.656 & 1.051 \\
\hline
\end{tabular}

the influence of the depth on the spectral response. The statistical properties of the two limnological parameters are shown in Tab. 2 . It is clear from the data that the conditions of the two lakes are significantly different: Lago Grande has a higher chlorophyll $a$ concentrations and lower transparency than Lago Piccolo. Here, the transparency is measured by averaging the disappearance and reappearance values of the Secchi Disk. In terms of the parameters considered by the OECD (Organization for Economic Co-operation and Development) Lago Piccolo is meso-oligotrophic, while Lago Grande is meso-eutrophic.

\section{Satellite data}

The remotely sensed data were acquired by the TM sensor onboard Landsat 5 . The scene (path 188, row 32) dates back to the 13/05/2001 (field data collection) and covers the whole Basilicata region. Weather conditions were stable between field data collection and satellite data, with no rain from 6 to 23 May, as reported from the Venosa meteorological station. The sensor's spectral characteristics are such that TM data is amongst the most used to monitor water quality.

Pre-processing of the Landsat data consisted of radiometric calibration and atmospheric correction: necessary for quantitative studies (Gordon 1987, Teillet et al. 1997). This is especially the case for surfaces such as lake waters where the reflected light is small (Maul 1985), since the radiance of these surfaces is less than $10 \%$ on average, and often lower than $1 \%$, of the sensor measured total radiance (Brivio et al. 2001b).

Radiometric calibration consists of a series of equations used to convert the stored quantized energy signal (digital number: $\mathrm{DN}$ ) of the TM data into radiance values at the sensor. Landsat images were converted into radiance values at the satellite by using the following equation (eqn. 1):

$$
L_{\text {sens }}=D N \cdot G+B
$$

where $\mathrm{L}_{\text {sens }}$ is the radiance at satellite level of a specific band $\left(\mathrm{W} \mathrm{m}^{-2} \mathrm{sr}^{-1} \mu^{-1}\right)$; $\mathrm{DN}$ is the value of the digital number; $G$ is the gain and $\mathrm{B}$ is the bias. The line intercept, described by the bias, takes into account the fact that even with a null input signal $\left(\mathrm{L}_{\text {sens }}=0\right)$ the acqui- sition system can still give an electric output signal fundamental to the acquisition system. The gain and offset values for the single bands were obtained from the CCT header file (Tab. 3).

Atmospheric correction is needed because electromagnetic radiation travels through the atmosphere along its two paths from the sun to the earth surface and from there to the sensor, undergoing alterations to the radiometric signal. For water, in particular, the sensor recorded radiometric signal is very weak compared to the atmosphere contribution (Brivio et al. 2006). Thus, the aim is to change the sensor recorded radiance into reflectivity of the surface at the ground. The simplified model of the effects of the atmosphere is (Moran et al. 1992 - eqn. 2):

$$
\rho_{\text {sup }}(\lambda)=\frac{\pi\left[L_{\text {sens }}(\lambda)-L_{\text {atm }}(\lambda)\right]}{\tau_{\uparrow}(\lambda)\left[E_{0}(\lambda) \cos \theta_{z} \tau_{\downarrow}(\lambda)+E_{\text {atm }}(\lambda)\right]}
$$

where $\rho_{\text {sup }}(\lambda)$ is the surface reflectivity; $\mathrm{L}_{\mathrm{atm} \uparrow}(\lambda)$ is the atmosphere spectral radiance (path radiance) diffused upward as $\mathrm{W} \mathrm{m}^{-2} \mathrm{sr}^{-1}$ $\mu \mathrm{m}^{-1} ; \mathrm{L}_{\text {sens }}(\lambda)$ is the sensor-measured spectral radiance; $\mathrm{E}_{0}(\lambda)$ is the solar spectral irradiance as $\mathrm{W} \mathrm{m}^{-2} \mu \mathrm{m}^{-1} ; \mathrm{E}_{\text {atm } \downarrow}(\lambda)$ is the downward spectral irradiance incident on the surface due to the diffusion of solar radiation through the atmosphere as $\mathrm{W} \mathrm{m} \mathrm{m}^{-2} \mu \mathrm{m}^{-1} ; \tau_{\uparrow}(\lambda)$ is the atmospheric transmittance along the sun-surface route; $\theta_{z}$ is the zenith angle of the sun.

The at-satellite radiance $\left(\mathrm{L}_{\text {sens }}\right)$ results from the radiometric calibration; $\mathrm{E}_{0}(\lambda)$ is the extra-atmospheric solar constant $\left[\mathrm{E}_{\text {sol }}=\mathrm{E}_{0}(\lambda)\right.$ $\cos \theta_{z}$ ], where the zenith angle of the sun $\left(\theta_{z}\right)$ was calculated from the date, position and time of satellite overpass while $\theta_{\mathrm{v}}$ (view angle) was assigned a value of $0^{\circ}$, which is considered an acceptable approximation for narrow FOV systems such as Landsat. The solution of the unknown terms is carried out by using several methods, which can be grouped in two categories: image based methods (used in this study) and radiative transfer models. The latter solve the equation on the base of the theory of the radiation

Tab. 3 - Gain and offset for Landsat TM5 bands.

\begin{tabular}{lcccccc}
\hline \multicolumn{1}{c}{ Bands } & $\mathbf{1}$ & $\mathbf{2}$ & $\mathbf{3}$ & $\mathbf{4}$ & $\mathbf{5}$ & $\mathbf{7}$ \\
\hline Offset & -1.5 & -2.8 & -1.2 & -1.5 & -0.37 & -0.15 \\
Gain & 0.6024 & 1.1749 & 0.8059 & 0.8145 & 0.1081 & 0.0570 \\
\hline
\end{tabular}

transfer of electromagnetic energy interacting with the atmosphere but need in situ measurements of atmosphere optical properties at the time of the satellite overpass. The image-based method used in this study belongs to the Dark Object Subtraction (DOS) category where information on atmosphere properties is obtained directly from image analysis. Briefly, the unknown terms of the general equation of the atmosphere correction are: $L_{\text {atm } \uparrow}(\lambda)$ : path radiance; $E_{\text {atm }}(\lambda)$ : downward atmosphere irradiance; $\tau_{\uparrow}(\lambda)$ : upward atmospheric transmittance; $\tau_{\downarrow}(\lambda)$ : downward atmospheric transmittance.

In the method we use, spectral irradiance due to solar radiation in the atmosphere is considered null $\left[\mathrm{E}_{\mathrm{atm} \downarrow}(\lambda)=0\right]$, while the path radiance $\left[L_{a t m \uparrow}(\lambda)\right]$ is obtained from the radiance measured by satellite of a pixel having no or very little reflectivity (dark object). In this study the dark object used was a pixel related to deep water off the Tyrrhenian coast (Chavez 1988, Teillet \& Fedoseievs 1995). This value, extracted for each Landsat band, is considered to be an additive contribution to total atmospheric radiance and thus subtracted from each band.

Downward atmospheric transmittance $\left[\tau_{\downarrow}(\lambda)\right]$ is approximated from the zenith angle of the sun (Chavez 1996 - eqn.3):

$$
\tau_{\downarrow}(\lambda)=\cos \theta_{z}
$$

an approximation valid for wavelengths up to $1.1 \mu \mathrm{m}$, while for greater wavelengths (i.e., TM5 and TM7) it is considered to be 1 .

The upward transmittance is calculated from the following equation (eqn. 4):

$$
\tau_{\uparrow}(\lambda)=e^{-\delta_{R}(\lambda) / \cos \theta_{v}}
$$

assuming there is only Rayleigh and not aerosol scattering. The Rayleigh optical thickness $\left[\delta_{R}(\lambda)\right]$ was calculated according to the equation (eqn. 5):

$$
\delta_{R}(\lambda)=0.008569 \lambda^{-4}\left(1+0.0113 \lambda^{-2}+0.00013 \lambda^{-4}\right)
$$

where $\lambda$ is the wavelength in $\mu \mathrm{m}$.

The corrected Landsat bands were subset to the area of interest and georeferred to the UTM-WGS84 system using 20 GCP before extracting the radiometric values of the limnological data at the sampling points. Average radiometric values were calculated for a $3 \times 3$ window centred on the sampling point (Forster et al. 1993, Brivio et al. 2001a).

\section{Results and discussion}

Common statistical techniques were used in order to determine the relationship between electromagnetic energy and water quality parameters (Lathrop \& Lillesand 
Tab. 4 - Pearson's $R$ correlation between limnological data and Landsat bands. (**): significant correlation for $\mathrm{p}<0.05$.

\begin{tabular}{lcc}
\hline \multicolumn{1}{c}{ Bands } & $\begin{array}{c}\text { Transparency } \\
\text { (SD) } \boldsymbol{m}\end{array}$ & $\begin{array}{c}\text { Chlorophyll } \boldsymbol{a} \\
\boldsymbol{m g} \boldsymbol{m}^{-3}\end{array}$ \\
\hline TM1 & $0.56^{* *}$ & $-0.59^{* *}$ \\
TM2 & 0.15 & $-0.32^{* *}$ \\
TM3 & -0.28 & 0.09 \\
TM4 & 0.11 & -0.21 \\
TM5 & 0.21 & -0.28 \\
TM7 & 0.21 & -0.29 \\
TM1/TM2 & 0.20 & -0.06 \\
TM2/TM1 & -0.14 & 0.04 \\
TM1/TM3 & $0.71^{* *}$ & $-0.54 * *$ \\
TM3/TM1 & $-0.67^{* *}$ & $0.47 * *$ \\
TM3/TM2 & $-0.81^{* *}$ & $0.68^{* *}$ \\
\hline
\end{tabular}

1986, Mayo et al. 1995, Kloiber et al. 2002a, Kloiber et al. 2002b). The functional models used to study the relation between reflectance values and limnological parameters, such as chlorophyll concentration and wate transparency, include linear, exponential and logarithmic transformation models.

First, an analysis using Pearson's correlation was carried out in order to detect the existence of significant relationships between Landsat bands and both transparency and chlorophyll concentration. Previous studies (Lathrop 1992, Lavery et al. 1993, Cox et al. 1998, Giardino et al. 2001, Kloiber et al. 2002a) found a very significant correlation between water transparency and the relationships among the visible bands, especially TM3/TM1. As regards to chlorophyll, some wavelengths are particularly important: 445 and $665 \mathrm{~nm}$ are the chlorophyll absorption bands, while 520 and $550 \mathrm{~nm}$ are points of minimum absorption (Arenz et al. 1996, Brivio et al. 2001a); thus, the Landsat visible bands are appropriate for detecting chlorophyll $a$ concentration in lake water (Giardino et al. 2001, Brivio et al. 2001a, Giardino 2006). The analyses carried out with Pearson's correlation (Tab. 4) are in agreement with results from the literature: the visible bands (particularly TM1 and TM2) and especially some of their ratios (TM1/TM3, TM3/ TM1, TM3/TM2) are significantly correlated

Tab. 5 - Regression analysis between limnological parameters and Landsat bands: (A) Secchi Disk depth; (B) chlorophyll $a$.

\begin{tabular}{|c|c|}
\hline $\begin{array}{l}\text { (A) Dependent } \\
\text { Variable }\end{array}$ & $\begin{array}{c}\text { SD } \\
\left(\mathrm{SD}[\mathrm{m}] ; \mathbf{T M}_{\mathrm{i}}\left[\mathrm{W} \mathbf{m}^{-2} \mathbf{s r}^{-1} \mu \mathrm{m}^{-1}\right]\right)\end{array}$ \\
\hline Previsional Model & $\mathrm{SD}=\mathrm{a}+\mathrm{bTM} 3 / \mathrm{TM} 2+\mathrm{cTM} 1 / \mathrm{TM} 2+\mathrm{dTM} 1+\mathrm{eTM} 2 / \mathrm{TM} 1$ \\
\hline \multirow[t]{5}{*}{ Coefficients } & 10.752 \\
\hline & -5.467 \\
\hline & -3.783 \\
\hline & 401.21 \\
\hline & -5.581 \\
\hline $\mathrm{R}^{2}$ & 0.82 \\
\hline \multirow[t]{4}{*}{$\mathrm{R}^{2}$ change } & TM3/TM2 \\
\hline & TM1/TM2 \\
\hline & TM1 \\
\hline & TM2/TM1 \\
\hline RMSE & 0.540 \\
\hline NSE & 0.943 \\
\hline$\underline{\mathrm{IA}}$ & 0.985 \\
\hline $\begin{array}{l}\text { (B) Dependent } \\
\text { Variable }\end{array}$ & $\begin{array}{c}\text { Chl-a } \\
\left(\text { Chl-a }\left[\mathrm{mg} \mathrm{m}^{-3}\right] ; \mathbf{T M}_{\mathrm{i}}\left[\mathrm{W} \mathrm{m}^{-2} \mathrm{sr}^{-1} \mu \mathrm{m}^{-1}\right]\right)\end{array}$ \\
\hline Previsional Model & $\mathrm{Ch} 1-\mathrm{a}=\mathrm{a}+\mathrm{bTM} 3 / \mathrm{TM} 2+\mathrm{cTM} 1 / \mathrm{TM} 2+\mathrm{dTM} 2+\mathrm{eTM} 2 / \mathrm{TM} 1$ \\
\hline \multirow[t]{5}{*}{ Coefficients } & -47.515 \\
\hline & 9.516 \\
\hline & 20.952 \\
\hline & -873.0 \\
\hline & 34.889 \\
\hline $\mathrm{R}^{2}$ & 0.72 \\
\hline \multirow[t]{4}{*}{$\mathrm{R}^{2}$ change } & TM3/TM2 \\
\hline & TM1/TM2 \\
\hline & TM2 \\
\hline & TM2/TM1 \\
\hline$\overline{\mathrm{RMSE}}$ & 1.300 \\
\hline NSE & 0.754 \\
\hline IA & 0.925 \\
\hline
\end{tabular}

with transparency and chlorophyll concentration.

As for the independent variables, all the visible bands and their ratios were included in the multiple regression. The procedure to select significant variables is the stepwise one, with $\mathrm{p}>0.10$ as a limit for factor removal.

As for transparency, the variables selected by the statistical analysis were TM1 and the TM3/TM2, TM1/TM2 e TM2/TM1 ratios. Therefore, the functional model is (eqn. 6):

$$
S D=a+b \frac{T M 3}{T M 2}+c \frac{T M 1}{T M 2}+d T M 1+e \frac{T M 2}{T M 1}
$$

where SD is the Secchi Disk measure in $\mathrm{m}$ and $\mathrm{TM}_{\mathrm{i}}$ are the Landsat bands, with radiometric and atmospheric correction, as $\mathrm{W}$ $\mathrm{m}^{-2} \mathrm{sr}^{-1} \mu \mathrm{m}^{-1}$. In Tab. 5, the results of the regression analysis are shown.

Data analysis confirms the ability of radiometric values, as derived from the Landsat bands, to predict lake water transparency. Very high $\mathrm{R}^{2}$ values were found and were in agreement with similar studies (Giardino et al. 2001, Kloiber et al. 2002a, KKloiber et al. $2002 \mathrm{~b})$ and RMSE was within moderate values.

In order to assess model performance we used two indices: the Index of Agreement (IA - Willmott 1981) and the Nash and Sutcliffe Efficiency coefficient (NSE - Nash \& Sutcliffe 1970). The IA and NSE indices high values detected (Tab. 5) confirm the reliability of the fitting model. The ratios among visible bands can be used to predict SD very well, as already shown in previous studies (Lathrop 1992, Lavery et al. 1993, Cox et al. 1998, Kloiber et al. 2002a, Giardino 2006): Among the single bands the TM1 showed the best relationship with SD, as suggested by the correlation analysis. On the other hand, even if the TM1/TM3 ratio showed a good correlation, it has been excluded from the functional model, as it was not statistically significant in the regression analysis. This behaviour is due to the high collinearity with the other independent variables included in the model.

On the other hand, the ratio TM3/TM2 was very significant accounting for $66 \%$ of SD variation; adding further terms to the functional model improves the prediction significantly reducing RMSE. The model, however, tends to slightly overestimate SD when values are low. The residuals values, the difference between predicted and observed values, show higher variability when the limnological values are low, e.g., in Lago Grande (Fig. 2), supporting the argument that it is difficult to derive low limnological parameter values from radiometric ones (Giardino et al. 2001).

The variability of chlorophyll $a$ concentration was investigated using the same procedure, incorporating visible bands and their 
Fig. 2 - Observed and predicted Secchi Disk values with the $95 \%$ confidence and prediction limits (dashed and dash dotted lines, respectively) of the regression model.

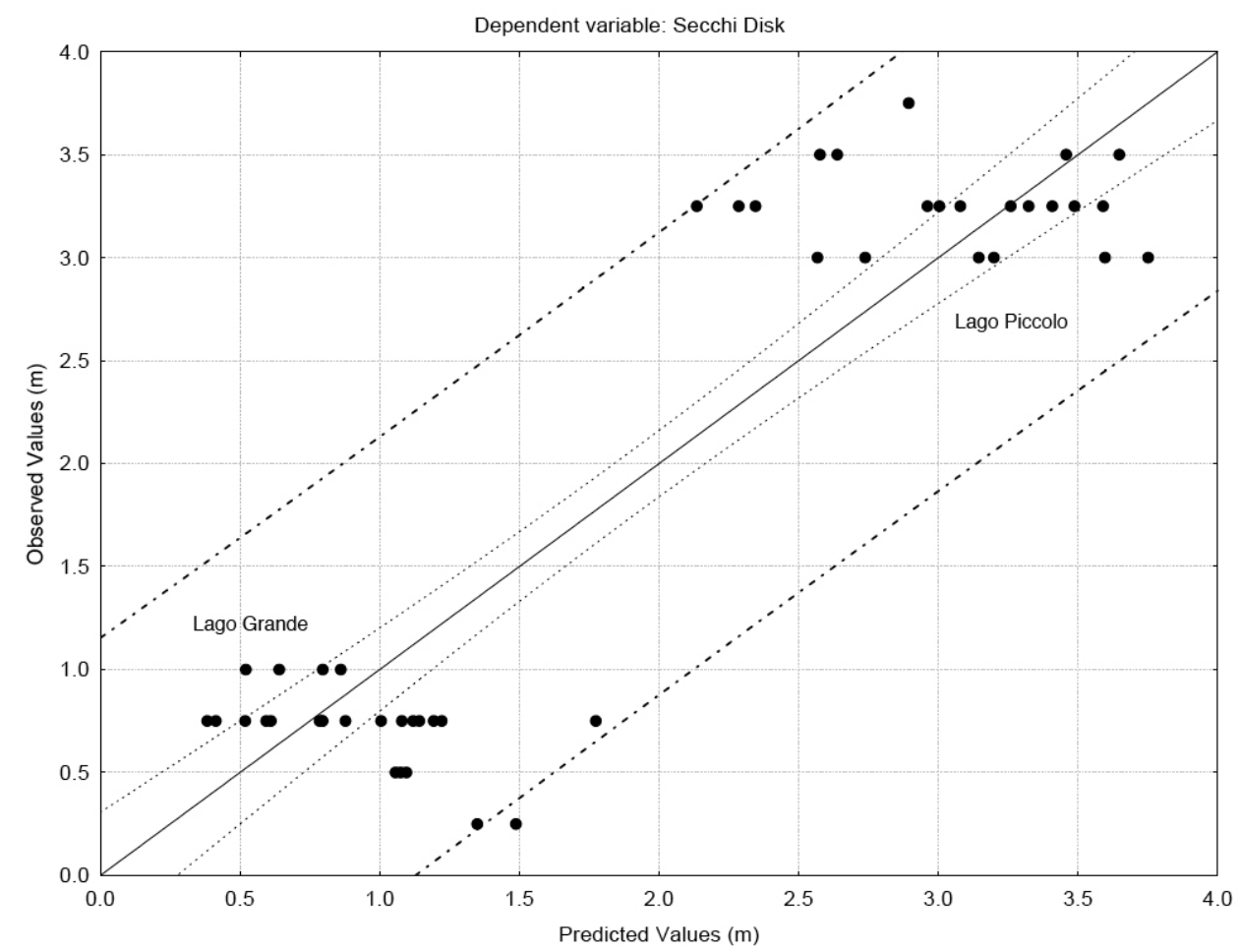

ratios as independent variables in regression analysis. From the stepwise variable selection procedure the following functional model was selected (eqn. 7):

$$
C h l-a=a+b \frac{T M 3}{T M 2}+c \frac{T M 1}{T M 2}+d T M 2+e \frac{T M 2}{T M 1}
$$

where Chl-a is the chlorophyll $a$ concentration in $\mathrm{mg} \mathrm{m}^{-3}, \mathrm{TM}_{\mathrm{i}}$ are the radiometric and atmospheric corrected Landsat bands in $\mathrm{W}$ $\mathrm{m}^{-2} \mathrm{sr}^{-1} \mu \mathrm{m}^{-1}$. Regression analysis (Tab. 5, Fig. 3) shows that the ratios among visibile bands of Landsat are very accurate predictors of chlorophyll $a$ concentration: the ratio TM3/TM2 accounts for $50 \%$ of the variation of the studied parameter, the TM2/TM1 ratio and the TM2 band have significant contributions as expected.
The determination coefficient $\mathrm{R}^{2}$ has quite a high value, in line with similar studies (Giardino et al. 2001, Brivio et al. 2001a, Giardino 2006). Moreover the IA and NSE indices, 0.925 and 0.754 respectively (Tab. 5 ), confirm the reliability of model estimates.

Having identified the regression functions for transparency and chlorophyll $a$ concen-

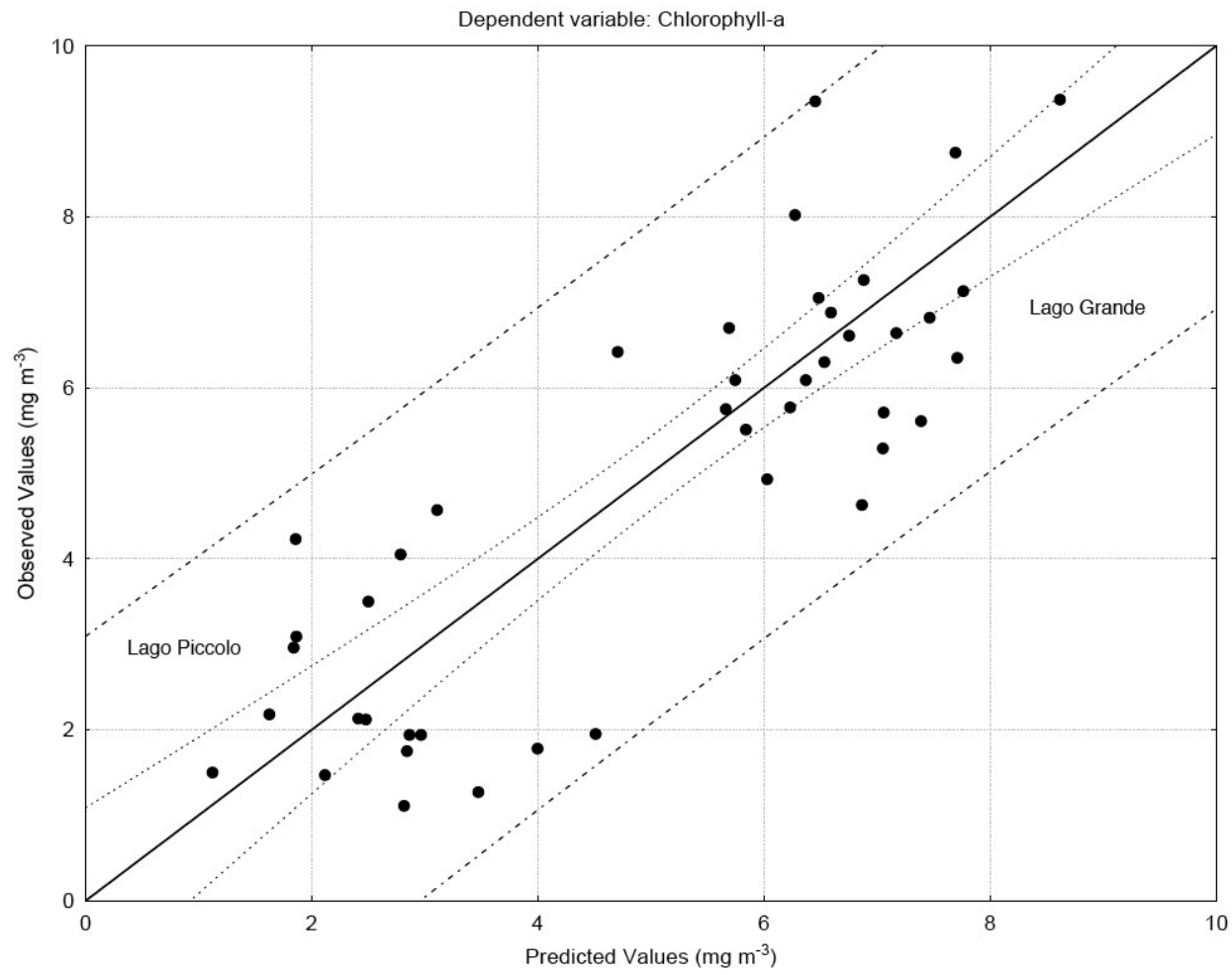

Fig. 3 - Observed and predicted values of chlorophyll a concentration with the $95 \%$ confidence and prediction limits (dashed and dash dotted lines, respectively) of the regression model. 

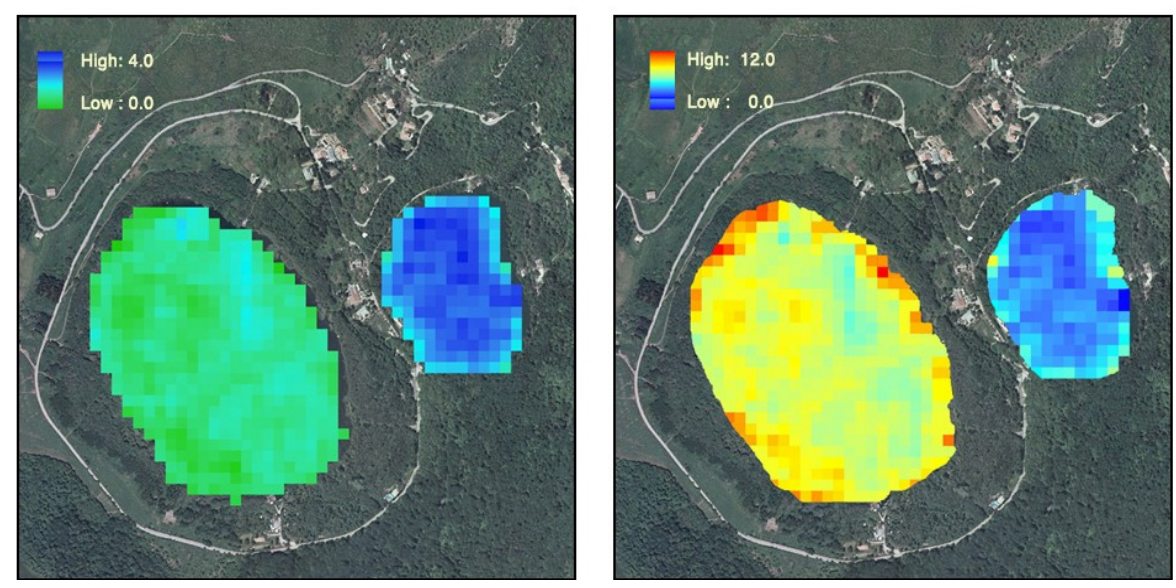

Fig. 4 - Transparency (left) and chlorophyll $a$ concentration (right) mapping of the two lakes.

tration the two limnological parameters were thus mapped for the whole lake surface of the two basins (Fig. 4). Both transparency and chlorophyll $a$ concentration show very different conditions in the two water bodies transparency values are considerably higher for Lago Piccolo than for Lago Grande (which rarely exceeds $1 \mathrm{~m}$ depth). This is mostly due to the different chlorophyll $a$ concentrations in the two lakes: in Lago Piccolo the chlorophyll values are $2.5 \mathrm{mg} \mathrm{m}^{-3}$ on average, with values up to a maximum of 4.5 $\mathrm{mg} \mathrm{m} \mathrm{m}^{-3}$, while in Lago Grande the mean value is $6.8 \mathrm{mg} \mathrm{m}^{-3}$, with values up to a maximum of $10 \mathrm{mg} \mathrm{m}^{-3}$.

The correlation between transparency and chlorophyll $a$ concentration (Kloiber et al. 2002b) was also determined by correlating the two limnological parameters for all the pixels of the lake surface (Fig. 5). The linear relation between the two parameters (chl-a $=$ $8.864-2.112 \cdot \mathrm{SD})$ is strong and significant with $\mathrm{R}^{2}=0.93$ and SEE (Standard Error of Estimate) $=0.6$.

Finally, the maps created of chlorophyll $a$ concentration and transparency were reclassified taking into account the ranges considered by OECD in order to define the trophic conditions of the two water bodies (Tab. 6).

Most of Lago Grande has transparency values lower than $1.5 \mathrm{~m}$, which is typical of a hypertrophic lake and $83.2 \%$ of the chlorophyll concentration values have characteristics of mesotrophic lakes; only 17\% (mainly concentrated in lake western part), has a concentration typical of eutrophic lakes.

Most of Lago Piccolo has transparency values exceeding $3 \mathrm{~m}$, which is typical of mesotrophic lakes, although an important part (around 35\%) has eutrophic lake characteristics. Chlorophyll $a$ concentration values are such that they characterize the lake as meso-oligotrophic: $95 \%$ of the values range from 2.5 to $8 \mathrm{mg} \mathrm{m}^{-3}$.

From the results, it can be stated that satellite remotely sensed data, especially data from Landsat, can be used effectively to assess the limnological parameters of lake waters. Radiometric data from Landsat can be used to map the areal distribution of some water biophysical parameters even for small basins such as the Monticchio lakes.

Data from the new sensors, such as Modis, can have a high temporal frequency (Lillesand et al. 2004, Li \& Li 2004) and facilitate atmospheric correction (Kloiber et al. 2002b), whilst being able to provide direct information on absorption and atmospheric scattering, unfortunately, they have the disadvantage of low spatial resolution which precludes their use on small water basins. On the other hand, data from high definition sensors, such as Ikonos, although used in different ways to study limnological parameters of inland waters, have the disadvantage of high costs making water resource management of large areas prohibitively expensive.

Fig. 5 - Correlation between transparency (SD) and chlorophyll $a$ concentration.

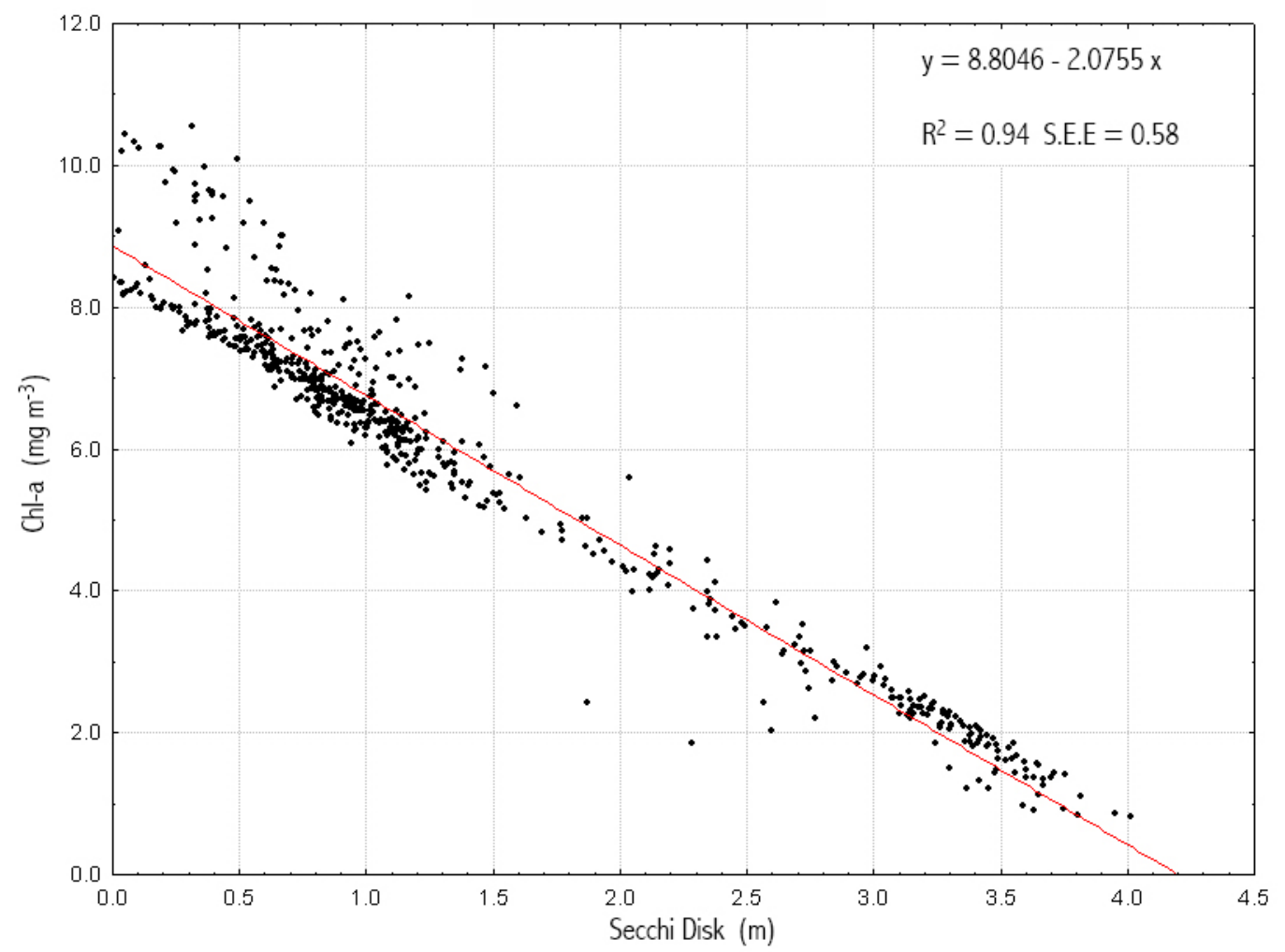


Tab. 6 - The area based chlorophyll concentration and transparency according to the OECD classification ranges.

\begin{tabular}{|c|c|c|c|c|c|c|c|c|c|}
\hline \multirow{3}{*}{$\begin{array}{l}\text { Range } \\
\text { OECD }\end{array}$} & \multicolumn{4}{|c|}{ Transparency (SD) m } & \multirow{3}{*}{$\begin{array}{l}\text { Range } \\
\text { OECD }\end{array}$} & \multicolumn{4}{|c|}{ Chlorophyll $a \mathrm{mg} \mathrm{m}^{-3}$} \\
\hline & \multicolumn{2}{|c|}{ Lago Grande } & \multicolumn{2}{|c|}{ Lago Piccolo } & & \multicolumn{2}{|c|}{ Lago Grande } & \multicolumn{2}{|c|}{ Lago Piccolo } \\
\hline & $\begin{array}{c}\text { Area } \\
\text { (ha) }\end{array}$ & $\%$ & $\begin{array}{c}\text { Area } \\
\text { (ha) }\end{array}$ & $\%$ & & $\begin{array}{c}\text { Area } \\
\text { (ha) }\end{array}$ & $\%$ & $\begin{array}{c}\text { Area } \\
\text { (ha) }\end{array}$ & $\%$ \\
\hline$<1.5$ & 39.7 & 96.2 & 0.25 & 1.8 & $\leq 1$ & - & - & 0.67 & 4.8 \\
\hline $1.5-3$ & 1.6 & 3.8 & 4.91 & 35.3 & $\leq 2.5$ & - & - & 7.66 & 55.1 \\
\hline $3-6$ & - & - & 8.74 & 62.9 & $2.5-8$ & 34.6 & 83.2 & 5.57 & 40.1 \\
\hline $6-12$ & - & - & - & - & $8-25$ & 6.9 & 16.8 & - & - \\
\hline$>12$ & - & - & - & - & $>25$ & - & - & - & - \\
\hline
\end{tabular}

Landsat data, on the other hand, has the advantages of reasonable spatial resolution, so that it can be used even for very small lake surfaces, and cover wide areas, allowing the management of inland waters at the regional level (Brezonik et al. 2005, Kloiber et al. 2002b). Finally, the fact that historical archives of Landsat data stretch back to the seventies allows the evolution of the biophysical characteristics of lake water to be studies.

\section{Conclusions}

A strong, significant, relationship was found between the spectral data in the TM bands with both chlorophyll concentration $\left(\mathrm{R}^{2}=0.72\right)$ and with transparency $\left(\mathrm{R}^{2}=\right.$ $0.82)$ measured as Secchi Disk depth. Multiple regression analysis on remote sensing data allowed to efficiently define the models and identify statistically significant variables. The ratios among visible bands and, most significantly, between TM3 and TM2 were good predictors both of transparency and chlorophyll concentration. The TM3 and TM2 bands have opposing trends in reflectance as a function of chlorophyll concentration: an increase of chlorophyll $a$ concentration markedly increases reflectance in band TM2 whereas it results in a stronger absorbance in band TM3.

The two parameters can be mapped for the whole lake surface by identifying the best set of band combinations to describe the relationship linking spectral response to limnological data. The same method can be applied to the trophic conditions. In our case the synoptic view showed a different states of two small lakes providing a basis for a targeted intervention strategy.

\section{Acknowledgments}

This work was supported by EC - Interreg III B WETMUST project (code A.1.042).

\section{References}

Arenz RF, Lewis WM, Saunders JF (1996). Determination of chlorophyll and dissolved organic carbon from reflectance data for Colorado reservoirs. International Journal of Remote Sensing

\section{7: $\quad 1547-1566$.}

doi:

$10.1080 /$

\section{3}

Baban SMJ (1993). Detecting water quality parameters in the Norfolk Broads, U.K., using Landsat imagery. International Journal of Remote Sensing 14: 1247-1267. - doi: 10.1080/ 01431169308953955

Brezonik P, Menken KD, Bauer M (2005). Landcharacteristics, including chlorophyll and coloured dissolved organic matter (CDOM). Lake and Reservoir Management 4: 373-382. - doi: 10.1080/07438140509354442

Brivio AP, Lechi G, Zilioli E (2006). Principi e metodi di telerilevamento. Città Studi Edizioni, Novara, Italy.

Brivio PA, Giardino C, Zilioli E (2001a). Determination of chlorophyll concentration changes in Lake Garda using an image-based radiative transfer code for Landsat TM images. International Journal of Remote Sensing 22: 487-502. doi: 10.1080/014311601450059

Brivio PA, Giardino C, Zilioli E (2001b). Validation of satellite data for quality assurance in lake monitoring application. The Science of the Total Environment 268: 19-29. - doi: 10.1016/S00489697(00)00693-8

Bukata RP, Burton JH, Jerome JH (1983). Use of chromaticity in remote measurements of water quality. Remote Sensing of Environment 13: 161-177. - doi: 10.1016/0034-4257(83)90020-2

Bukata RP, Jerome JH, Kondratiev KY, Pozdnyakov DV (1995). Optical properties and remote sensing of inland coastal waters. CRC Press, Boca Raton, FL, USA. (2005). Monitoring water quality of the perialpine Italian Lake Garda trough multi-temporal MERIS data. Meris-(A) ATSR Workshop, Frascati (Italy) 26-30 September 2005. ESA, CDROM, ISBN 92-9092-908-1.

Caselles V, Lopez Garcia MJ (1989). An alternative approach to estimate atmospheric correction in multitemporal studies. International Journal of Remote Sensing 10: 1127-1134. - doi: 10.1080/ 01431168908903951

Chavez PS (1988). An improved dark object subtraction technique for atmospheric scattering correction of multispectral data. Remote Sensing of Environment 24: 459-479. - doi: 10.1016/0034sat-based remote sensing of lake water quality

Candiani G, Floricioiu D, Giardino C, Rott H
4257(88)90019-3

Chavez PS (1996). Image-based atmospheric corrections - revisited and improved. Photogrammetric. Engineering and Remote Sensing 62: 1025-1036.

Cox RM, Forsythe RD, Vaughan GE, Olmsted LL (1998). Assessing water quality in the Catawba River reservoirs using Landsat thematic mapper satellite data. Lake and Reservoir Management 14: 405-416. - doi: 10.1080/07438149809354347 Dekker AG, Peters SWM (1993). The use of the Thematic Mapper for the analysis of eutrophic lakes: a case study in the Netherlands. International Journal of Remote Sensing 14: 799-821. doi: 10.1080/01431169308904379

Dumontet S, Scopa A, Pasquale V, Franzese PP, Melchiorre R, Pariti L, Attolico A, Allegretti G (2001). Studio delle caratteristiche morfometriche, limnologiche e chimico/microbiologiche dei Laghi di Monticchio. Assessorato Assetto e Programmazione del Territorio-Ambiente, Provincia di Potenza, Potenza, Italy.

Forster BC, Xingwei S, Baide X (1993). Remote sensing of sea water quality parameters using Landsat TM. International Journal of Remote Sensing 14: 2759-2771. - doi: 10.1080/ 01431169308904307

Fraser RS (1998). Multispectral remote sensing of turbidity among Nebraska sand hills lakes. International Journal of Remote Sensing 19: 30113016. - doi: 10.1080/014311698214406

Fraser RS, Ferrare RA, Kaufman YJ, Markham BL (1992). Algorithm for atmospheric corrections of aircraft and satellite images. International Journal of Remote Sensing 13: 541-557. - doi: 10.1080/01431169208904056

George DG (1997). The airborne remote sensing of phytoplankton chlorophyll in the lake and tarns of the English Lake District. International Journal of Remote Sensing 18: 1961-1975. - doi: 10.1080/014311697217972

Giardino C, Pepe M, Brivio PA, Ghezzi P, Zilioli E (2001). Detecting chlorophyll, Secchi disk depth and surface temperature in a sub-alpine lake using Landsat imagery. The Science of the Total Environment 268: 19-29. - doi: 10.1016/S0048-9697(00)00692-6

Giardino C (2006). Telerilevamento per la qualità delle acque interne. In: "Telerilevamento Applicato". Mako Edizioni, Quartu S.E., Italy, pp. $307-$ 320.

Giardino C, Candiani G, Zilioli E (2005). Detecting chlorophyll-a in Lake Garda (Italy) using TOA MERIS radiances. Photogrammetric Engineering and Remote Sensing 71: 1045-1052. [online] URL: http://md1.csa.com/partners/viewrecord.php?requester $=$ gs \& collection $=$ ENV\&recid $=$ $7487181 \& q=\& u i d=787328419 \&$ setcookie $=$ yes

Gitelson AA, Jacobi YZ, Schalles JF, Rundquist DC, Han L, Stark R, Etzion D (2000). Remote estimation of phytoplankton density in productive waters. Archives of Hydrobiology and Advanced Limnology 55: 121-136.

Gordon HR (1987). Calibration requirements and methodology of remote sensors viewing the oceans in the visible. Remote Sensing and Envi- 
ronment 22: 103-126. - doi: 10.1016/00344257(87)90029-0

Green S (2003). The effect of chlorophyll concentration on airborne hyperspectral reflectance. [online] URL: http://www.ucd.ie/ app-phys/stuart/MODEL.HTM

Jaquet JM, Zand B (1989). Colour analysis of inland water using Landsat TM data. In: "Monitoring the earth's environment". Publication ESA, SP-1102, pp. 57-67.

Kaufman YJ, Sendra C (1988). Algorithm for automatic correction to visible and near-infrared satellite imagery. International Journal of Remote Sensing 9: 1357-1381. - doi: 10.1080/ 01431168808954942

Kaufman YJ (1989). The atmospheric effect on remote sensing and its correction. In: "Theory and application of optical remote sensing". John Wiley and Sons, New York, USA, pp. 336-428.

Kloiber SM, Brezonik PL, Bauer ME (2002b). Application of Landsat imagery to regional-scale assessments of lake clarity. Water Research 36 4330-4340. - doi: 10.1016/S0043-1354(02)00146 $-\mathrm{X}$

Kloiber SM, Brezonik PL, Olmanson LG, Bauer ME (2002a). A procedure for regional lake water clarity assessment using Landsat multispectral data. Remote Sensing of Environment 82: 38-47. - doi: 10.1016/S0034-4257(02)00022-6

Lathrop RG (1992). Landsat Thematic Mapper monitoring of turbid inland water quality. Photogrammetric Engineering and Remote Sensing 58: 465-470

Lathrop RG, Lillesand TM (1986). Use of Thematic Mapper data to assess water quality in Green Bay and Central Lake Michigan. Photogrammetric Engineering and Remote Sensing 52: 671680. [online] URL: http://cat.inist.fr/?aModele= afficheN\&cpsidt $=8815529$

Lavery P, Pattiaratchi C, Wyllie A, Hick P (1993). Water quality monitoring in estuarine waters using the Landsat Thematic Mapper. Remote Sensing of Environment 3: 268-280. - doi 10.1016/0034-4257(93)90047-2

Leoni B, Garibaldi L (2009). Population dynamics of Chaoborus flavicans and Daphnia spp.: effects on a zooplankton community in a volcanic eutrophic lake with naturally high metal concentrations (L. Monticchio Grande, southern Italy) Journal of Limnology 68 (1): 37-45. [online] URL: http://surplus-unibic.cilea.it/oa/handle/ 10281/6122? mode=simple

Li R, Li J (2004). Satellite remote sensing technology for lake water clarity monitoring: an overview. Environmental Informatics Archives 2: 893-901

Lillesand TM, Kiefer RW, Chipman JW (2004). Remote sensing and Image Interpretation. John
Wiley and Sons, New York, USA.

Lillesand TM, Johnson WL, Deuell R L, Lindstrom OM, Meisner DE (1983). Use of Llndsat data to predict the trophic state of Minnesota lakes. Photogrammetric Engineering and Remote Sensing 49: 219-229.

Lindell T, Karlsson B, Rosengren M, Alfoldi TT (1986). A further development of the chromaticity technique for satellite mapping of suspended sediment load. Photogrammetric Engineering and Remote Sensing 52: 1521-1530. [online] URL: http://cat.inist.fr/?aModele $=$ afficheN\&cpsidt= 8140288

Maul GA (1985). Introduction to satellite oceanography. Martinus Nijhoff Publishers, Dordrecht/ Boston/Lancaster.

Mayo M, Gitelson A, Yacobi YZ, Ben-Avraham Z (1995). Chlorophyll distribution in Lake Kinneret determined from Landsat Thematic Mapper data. International Journal of Remote Sensing 16: 175-182. - doi: 10.1080/01431169508954386 Ministero dell'Ambiente e della Tutela del Territorio e del Mare (2007). Laghi vulcanici: il fuoco, l'acqua e la vita. Quaderni Habitat 17, Roma, Italy, pp. 53.

Moran MS, Jackson JD, Slater PN, Teillet PM (1992). Evaluation of simplified procedures for retrieval of land surface reflectance factors from satellite sensor output. Remote Sensing of Environment 41: 169-184. - doi: 10.1016/00344257(92)90076-V

Nash JE, Sutcliffe JV (1970). River flow forecasting through conceptual models, Part I - A discussion of principles. Journal of Hydrology 10: 282:290. - doi: 10.1016/0022-1694(70)90255-6

Richter R (1990). A fast atmospheric correction algorithm applied to Landsat TM images. International Journal of Remote Sensing 11: 159-166. - doi: 10.1080/01431169008955008

Ritchie R, Cooper CM, Schiebe FR (1990). The relationship of MMS and TM digital data with suspended sediments, chlorophyll and temperature in Moon lake, Mississippi. Remote Sensing of Environment 33: 137-148. - doi: 10.1016/0034-4257(90)90039-O

Sass GZ, Creed IF, Bayley S.E, Devito KJ (2007). Understanding variation in trophic status of lake on Boreal Plain: a 20 year retrospective using Landsat TM imagery. Remote Sensing of Environment 109: 127-141 - doi: 10.1016/j.rse.2006. 12.010

Schiebe FR, Harrington JA, Ritchie JC (1992). Remote sensing of suspended sediments: the Lake Chicot, Arkansas project. International Journal of Remote Sensing 13: 1487-1509. - doi: 10.1080/01431169208904204

Schneider K, Mauser W (1996). Processing and accuracy of Landsat thematic mapper for lake surface temperature measurement. International Journal of Remote Sensing 11: 2027-2041. - doi: 10.1080/01431169608948757

Strombeck N, Candiani G, Giardino C, Zilioli E (2003). Water quality monitoring of Lake Garda using multi-temporal MERIS data. Meris-(A) ATSR Workshop, Frascati (Italy) 10-13 November 2003. ESA, CD-ROM, ISBN 92-9092-860-3. Teillet PM, Horler DNH, O'Neill NT (1997). Calibration, validation and quality assurance in remote sensing: a new paradigm. Canadian Journal of Remote Sensing 4: 401-414. [online] URL: http://md1.csa.com/partners/viewrecord.php?requester $=$ gs\&collection $=$ TRD\&recid $=$ A9840671 AH\&q $=$ \&uid $=787328419 \&$ setcookie $=$ yes

Teillet PM, Fedoseievs G (1995). On the dark target approach to atmospheric correction of remotely sensed data. Canadian Journal of Remote Sensing 21: 374-387.

Vermote EF, Tanré D, Denzé JL, Herman M, Morcrette JJ (1997). Second simulation of the satellite signal in the solar spectrum, 6S: an overview. IEEE Transaction on Geoscience and Remote Sensing 35: 675-686. - doi: 10.1109/ 36.581987

Vincent RK, Qin X, McKay ML, Miner J, Czajkowski K, Savino J, Bridgeman T (2004). Phycocyanin detection from LANDSAT TM data for mapping cyanobacterial blooms in Lake Erie. Remote Sensing of Environment 89: 381-392 doi: 10.1016/j.rse.2003.10.014

Wang Y, Xia H, Fu J, Sheng G (2004). Water quality change in reservoirs of Shenzhen: detection using Landsat/TM data. The Science of the Total Environment 328: 195-206. - doi: 10.1016/ j.scitotenv.2004.02.020

Willmott CJ (1981). On the validation of model. Phys. Geogr. 2: 184-194.

Zilioli E, Brivio PA (1997). The satellite derived optical information for the comparative assessment of lacustrine water quality. The Science of the Total Environment 196: 229-245. - doi: 10.1016/S0048-9697(96)05411-3

Zilioli E, Brivio PA, Gomarasca MA (1993). Spectral and chromaticity-based analysis of Landsat data for the chlorophyll assessment in the lakes Maggiore, Como and Garda. Proceeding of the $5^{\text {th }}$ International Conference on the "Conservation and Management of Lakes". Stresa (Italy) 17-21 May 1993, pp. 229-232.

Zilioli E, Brivio PA, Gomarasca MA (1994). A correlation between optical properties from satellite data and some indicators of eutrophication in Lake Garda (Italy). The Science of the Total Environment 158: 127-133. - doi: 10.1016/00489697(94)04249-M 